\title{
Investigation of growth rate variation between commercial pig herds
}

\author{
E. Magowan ${ }^{1 \dagger}$, M. E. E. McCann ${ }^{1,2}$, V. E. Beattie ${ }^{3}$, K. J. McCracken², W. Henry ${ }^{3}$, S. Smyth ${ }^{4}$, \\ R. Bradford ${ }^{4}$, F. J. Gordon ${ }^{4}$ and C. S. Mayne ${ }^{1,2}$ \\ ${ }^{1}$ Agri-Food and Biosciences Institute, Hillsborough, Large Park, Hillsborough, Co. Down BT26 6DR, Northern Ireland, UK; ${ }^{2}$ The Queen's University of Belfast, \\ Newforge Lane, Belfast BT9 5PX, UK; ${ }^{3}$ Devenish Nutrition Ltd., 96 Duncrue Street, Belfast BT3 9AR, UK; ${ }^{4}$ John Thompson \& Sons Ltd., 35-38 York Road, Belfast \\ BT15 3GW, UK
}

(Received 5 March 2007; Accepted 20 June 2007)

\begin{abstract}
The study was designed to provide quantifiable information on both within- and between-herd variation in pig growth rate from birth to slaughter and to examine how this was influenced by moving pigs at a common age to a common environment. Five litters were selected from each of eight pig herds in Northern Ireland with varying growth performance. All eight herds were offered the same nutritional regime. Five pigs (three boars and two gilts) were selected from each litter. In each herd, 22 pigs (12 boars and 10 gilts) were weighed individually, every 4 weeks, from 4 to 20 weeks of age. At 4 weeks of age (weaning) three non-sibling boars were taken from each herd and brought to a common environment where they received medication, were housed individually from 6 weeks of age and offered the same dietary regime. They were weighed and feed intakes were recorded twice weekly. A growth rate difference of $61 \mathrm{~g} /$ day $(\mathbb{P}<0.001), 112 \mathrm{~g} /$ day $(\mathrm{P}<0.01)$ and $170 \mathrm{~g} /$ day $(\mathrm{P}<0.001)$ was observed on farm, between the top and bottom quartile of herds during 4 to 8,8 to 12 and 12 to 20 weeks of age, respectively. This difference in growth rate equated to an average difference in cost of production of ф13/kg carcass on a birth to bacon unit. When pigs from the different herds were housed in the common environment, large variation in growth performance $(143 \mathrm{~g} /$ day $(\mathrm{P}<0.01)$ and $243 \mathrm{~g} /$ day $(\mathrm{P}<0.001)$ for 8 to 12 and 12 to 20 weeks, respectively) was also observed between the top and bottom quartile of herds. Although feed efficiency was similar, a significant feed intake difference of $329 \mathrm{~g} /$ day $(\mathrm{P}<0.01)$ and $655 \mathrm{~g} /$ day $(\mathrm{P}<0.001)$ between 8 to 12 and 12 to 20 weeks of age was observed. The variation in growth rate between pigs whether managed on farm or in the common environment was similar (variation in days to $100 \mathrm{~kg}$ on farm and in the common environment was 18 and 19 days, respectively). When housed in the common environment, although the top and bottom quartile of pigs converted feed equally efficiently, pigs in the top quartile had significantly higher feed intakes suggesting greater appetites. It is difficult to assess the extent to which these differences can be attributed to genetic effects or pre-weaning environment, and how much the effects of management, disease or genetics contributed to the variation between and within herds.
\end{abstract}

Keywords: commercial farming, performance, pigs, variation

\section{Introduction}

Variation in the growth rate of pigs starts from conception, with pigs of the same litter often varying considerably in birth weight (Milligan et al., 2001). This variation in pig growth performance both within and between litters continues through their lifetime (Kennedy, 1984). Growth rate is largely driven by feed intake (Whittemore and Green, 2001), hence variable growth rate is a reflection of variable

${ }^{\dagger}$ E-mail: elizabeth.magowan@afbini.gov.uk feed intake. Research by Geary and Brooks (1998) has shown that each $50 \mathrm{~g} /$ day increase in dry-matter feed intake in the week following weaning was associated with an increase of $870 \mathrm{~g}$ in 28-day post-weaning weight. Genetic and environmental factors contribute to variable feed intake within and between litters and herds of pigs. Environmentally, variable feed intake can be a result of, for example, birth weight, sex, weaning age, management system, disease status or diet composition (Pajor et al., 1991; Bruininx et al., 2001; Whittemore and Green, 2001; 0'Connell et al., 2002). Profitability is also highly variable between herds 
(Stein et al., 1990). Within Northern Ireland, the number of pigs produced per sow per year can vary by 4.4 and the overall profitability of herds by $€ 688$ per sow per year (Donnelly, 2006).

Many of the studies investigating variability have been conducted under controlled experimental conditions and those studies conducted in the field have only considered the average responses of herds, as opposed to responses of individual pigs within herds. It is recognised that studies of field data are important since results under controlled conditions do not always reflect responses in the field (David et al., 1983). The aim of this study was therefore to provide quantifiable information on both within- and between-herd variation in pig growth rate from birth to slaughter and to examine how this was influenced by moving pigs at a common age to a common environment.

\section{Material and methods}

Herds and animals

Eight herds with varying growth performance, offered the same diets from birth to slaughter, were selected from the pig herds of Northern Ireland. Six of the eight herds (B, C, D, $E, F$ and $H$ ) had a herd size between 150 and 200 sows while the remaining two herds ( $A$ and $G$ ) had a herd size of 500 sows. All pigs were $\frac{3}{4}$ Landrace $\times \frac{1}{4}$ Large White with their sires being from Northern Ireland studs. On six of the eight herds, pigs were housed in groups of 20 which remained static from weaning to slaughter. On the remaining two herds, pigs were grouped in batches of 60 at weaning and divided into batches of 20 at the beginning of the finishing stage. All herds were quality assured and therefore maintained high welfare standards, which included adequate floor space per pig, feeder space and water availability. In stage $1 /$ stage 2 , all pigs were offered dry pelleted feed from dry multispace feeders (Etra Feeders, Northern Ireland). In the finishing stages, all pigs were offered dry pelleted feed through wet and dry single space feeders (Verba, Verbakel ${ }^{\mathrm{TM}}$, The Netherlands). All pigs were housed on fully slatted flooring (plastic slats in stage $1 /$ stage 2 accommodation and concrete slats in the finishing stages) and houses were ventilated using 'automatic controlled fan ventilation'. Pigs were housed in stage 1 accommodation for 4 weeks, stage 2 accommodation for 4 weeks after which they were transferred to finishing accommodation where they remained until slaughter. All herds were diagnosed as enzootic pneumonia and porcine reproductive and respiratory syndrome (PRRS) (blue-ear disease) positive, one herd was Haemophilus parasuis positive and another herd suffered occasional infections of Escherichia coli in post-weaned pigs. All herds vaccinated for porcine parvovirus and leptospirosis. All herds were medicated in stage 1 with zinc oxide and chlorotetracycline (CTC) $10 \%$. The mean herd growth rate of pigs between 45 and $100 \mathrm{~kg}$ was taken from Benchmark data (Donnelly, 2004) and ranged from 673 to $1064 \mathrm{~g} /$ day.
Five litters were randomly selected from each of the eight herds. Within each litter, five pigs (three boars and two gilts) were selected at weaning and tagged. Pigs were selected by sex and weight. The medium weight of the litter was established after which one pig was selected to represent the medium weight and the remaining four pigs were selected either side of the medium weight, i.e. two below the medium weight and two above the medium weight. In total, 25 pigs were selected at weaning on each herd, of which 22 remained on the farm for performance testing and the remaining three (non-sibling boars) were transferred to a common controlled environment where they were housed with the seven other sets of 'three pigs' from the seven other herds in order to test their performance under controlled conditions. All pigs from all herds were born within 3 days of each other.

At birth, the weight of the litter of pigs was recorded and the average weight was taken as the initial birth weight. There was no difference in the management of pigs, within a herd, from birth to weaning at 4 weeks of age. All pigs were offered a creep feed (diet 1) pre-weaning.

\section{On-farm performance testing}

In each herd, the aforementioned selected 22 pigs ( 12 boars and 10 gilts) were randomly distributed across a number of pens of mixed weight pigs. These pigs were weighed individually every 4 weeks, from 4 to 20 weeks of age. The average daily gain (ADG) and coefficient of variation for weight of pigs in each herd was calculated. Pigs were offered commercial pig diets (Table 1) ad libitum. The duration of ad libitum feeding of each diet varied across pig herds due to producers adopting different diet management strategies.

\section{Economic evaluation}

Data on feed usage and efficiency and pig mortality for the top herd and the bottom herd were collected and these data, together with the average growth rate of the pigs on farm were inputted to an economic model (Devenish Nutrition Ltd, Belfast, UK) based on 1100 finishing places, to establish differences in profitability between herds. According to the herd $A D G$, the throughput of pigs from 1100 finisher pig places was calculated and hence equated to the financial output from the respective units. The economic model was based on an all in/all out system and there were no empty days between batches. The economic model was set to calculate the 'herd net profit' of a birth to bacon production system based on pigs being weaned at 26 days of age, being housed in stage 1 and stage 2 accommodations for 28 and 35 days, respectively, and being housed in finishing accommodation until they reached a live weight of $105 \mathrm{~kg}$. The model also included fixed costs per sow of veterinary expenses $(€ 29)$, labour $(€ 74)$, electric $(€ 22)$, artificial insemination $(€ 15)$, rent/ repayment $(€ 74)$, miscellaneous $(€ 29)$, repairs and maintenance $(€ 29)$ and transport/slurry $(€ 29)$. 
Table 1 Composition of diets offered to pigs on farm and in the common environment (as-fed basis)

\begin{tabular}{|c|c|c|c|c|c|}
\hline & & & Diet & & \\
\hline & 1 (starter) & 2 (starter) & 3 (link) & 4 (grower) & 5 (finisher) \\
\hline Ingredient $^{\dagger}$ & & & & & \\
\hline Wheat & $レ$ & レ & レ & レ & レ \\
\hline Barley & & & & レ & レ \\
\hline Maize & & 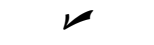 & レ & レ & レ \\
\hline Cooked cereal & レ & レ & & & \\
\hline Soya & $\boldsymbol{V}$ (toasted) & $\boldsymbol{\nu}$ (toasted) & レ & レ & レ \\
\hline Potato protein & レ & レ & & & \\
\hline Sugar & レ & & & & \\
\hline Pollard & & & & レ & レ \\
\hline Rapeseed extract & & & & レ & レ \\
\hline Natupro & & レ & 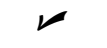 & & \\
\hline Whey & レ & レ & レ & & \\
\hline Molaferm & & & & レ & レ \\
\hline Vegetable oil blend & & & レ & レ & レ \\
\hline Soya oil & レ & レ & レ & レ & \\
\hline Limestone & レ & レ & レ & レ & レ \\
\hline Mono dicalcium phosphate & レ & レ & レ & レ & \\
\hline Salt & & レ & レ & レ & レ \\
\hline Lysine & レ & レ & レ & レ & レ \\
\hline Methionine & レ & 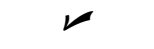 & & レ & \\
\hline L-Threonine & レ & レ & & レ & \\
\hline Tryptophane & レ & レ & & & \\
\hline Devicare & & & レ & & レ \\
\hline Chemical analysis & & & & & \\
\hline Dry matter $(\mathrm{g} / \mathrm{kg})$ & 896 & 885 & 890 & 877 & 877 \\
\hline Digestible energy (MJ/kg) & 16.6 & 16.0 & 15.1 & 14.8 & 14.0 \\
\hline Crude protein (g/kg) & 21.4 & 22.7 & 19.9 & 18.9 & 18.0 \\
\hline Oil A $(g / k g)$ & 9.7 & 7.8 & 6.5 & 6.1 & 4.7 \\
\hline Fibre $(\mathrm{g} / \mathrm{kg})$ & 2.4 & 2.5 & 2.8 & 2.9 & 4.5 \\
\hline Ash $(\mathrm{g} / \mathrm{kg})$ & 4.7 & 3.6 & 5.2 & 4.7 & 5.2 \\
\hline Digestible lysine $(\mathrm{g} / \mathrm{kg})$ & 1.21 & 1.26 & 1.10 & 0.97 & 0.86 \\
\hline
\end{tabular}

${ }^{+}$The diets were commercially manufactured by Devenish Nutrition Ltd (Belfast, UK) (Diets 1 and 2) and John Thompson and Sons Ltd (Diets 3, 4 and 5). The exact amount of each ingredient cannot therefore be disclosed, however a 'tick' represents the presence of the raw material in the diet.

\section{Performance testing under controlled conditions}

Three non-sibling boars, typical of pigs being weaned, were selected at 4 weeks of age in each of the eight herds. In order to select the three boars, three litters were first selected, from the five in each herd, according to their average litter weight, i.e. one litter represented the medium average litter weight and the other two litters had average litter weights either side of the medium. The boars were then selected from these litters according to their weight, which was representative of the average weight of the litter. Immediately after selection they were transferred to a common controlled environment. A total of 24 boars were transferred and mixed at 4 weeks of age in a common environment. They were group-housed to 6 weeks of age, after which they were individually housed until slaughter $(115 \mathrm{~kg}$ live weight). Pigs were offered the same commercial pig diets as on farm (Table 1) ad libitum in the following controlled manner (as-fed basis): diet 1, $3 \mathrm{~kg}$ per pig; diet 2, $7 \mathrm{~kg}$ per pig; diet 3, offered until pigs were $20 \mathrm{~kg}$; diet 4, offered from 20 to $40 \mathrm{~kg}$ live weight; and diet 5, offered from $40 \mathrm{~kg}$ live weight to slaughter. All pigs received in-feed medication through diets 1, 2 and 3 (3.1 kg/t Zn (Pigzin), $2 \mathrm{~kg} / \mathrm{t} \mathrm{Stabox}, 2 \mathrm{~kg} / \mathrm{t}$ Pulmotil G1 in each diet). Pigs were weighed individually and feed intakes calculated twice weekly until 20 weeks of age.

\section{Calculations and statistical analysis}

Individual pig data on farm and under controlled conditions were analysed by analysis of variance using Genstat (2002). Analysis of variance was used to test the effect of herd and the effect of the top and bottom quartile of herds on pig live weight and growth performance on farm and in the common environment. The estimated time taken for individual pigs to attain a live weight of $100 \mathrm{~kg}$ was calculated from individual pig ADG values. The coefficient of variation of pig weight within each farm was calculated by dividing the mean weight of pigs by the standard deviation of the 
Magowan, McCann, Beattie, McCracken, Henry, Smyth, Bradford, Gordon and Mayne

Table 2 Average weight $(\mathrm{kg})$ and daily gain ( $\mathrm{g} /$ day) of pigs on farm

\begin{tabular}{|c|c|c|c|c|c|c|c|c|c|c|}
\hline & \multicolumn{8}{|c|}{ Herd } & \multirow[b]{2}{*}{ s.e. } & \multirow[b]{2}{*}{ Significance } \\
\hline & $A$ & B & C & $\mathrm{D}$ & $\mathrm{E}$ & $\mathrm{F}$ & G & $\mathrm{H}$ & & \\
\hline \multicolumn{11}{|l|}{ Weight (kg) } \\
\hline Wean & $9.0^{\mathrm{de}}$ & $9.9^{\mathrm{e}}$ & $8.4^{\mathrm{bcd}}$ & $7.9^{\mathrm{abc}}$ & $8.7^{\mathrm{cd}}$ & $7.7^{\mathrm{ab}}$ & $7.4^{\mathrm{a}}$ & $8.7^{\mathrm{cd}}$ & 0.30 & $* * *$ \\
\hline 20 weeks & $81.5^{\mathrm{cd}}$ & $85.0^{\mathrm{d}}$ & $83.1^{d}$ & $76.3^{\mathrm{bc}}$ & $71.9^{\mathrm{ab}}$ & $71.1^{\mathrm{ab}}$ & $69.3^{\mathrm{a}}$ & $67.7^{\mathrm{a}}$ & 2.20 & $* * *$ \\
\hline \multicolumn{11}{|c|}{ Average daily gain (g/day) } \\
\hline 0 to 4 weeks & $262^{c}$ & $277^{d}$ & $239^{c}$ & $234^{\mathrm{bc}}$ & $252^{c}$ & $205^{\mathrm{ab}}$ & $199^{\mathrm{a}}$ & $245^{c}$ & 10.6 & $* * *$ \\
\hline 4 to 8 weeks & $368^{\mathrm{cd}}$ & $424^{e}$ & $384^{\text {de }}$ & $309^{b}$ & $327^{\mathrm{bc}}$ & $227^{\mathrm{a}}$ & $360^{\mathrm{cd}}$ & $326^{b c}$ & 14.9 & $* * *$ \\
\hline 8 to 12 weeks & $649^{e}$ & $590^{\text {de }}$ & $596^{\text {de }}$ & $453^{\mathrm{ab}}$ & $522^{\text {bcd }}$ & $517^{\text {bcd }}$ & $526^{\text {bcd }}$ & $435^{\mathrm{a}}$ & 24.3 & $* * *$ \\
\hline 12 to 20 weeks & $762^{\mathrm{cd}}$ & $803^{c d}$ & $817^{d}$ & $815^{d}$ & $673^{a b}$ & $734^{\mathrm{bc}}$ & $629^{a}$ & $651^{a}$ & 25.7 & $* * *$ \\
\hline 0 to 20 weeks & $557^{\mathrm{cd}}$ & $577^{d}$ & $568^{d}$ & $522^{\mathrm{bc}}$ & $489^{a b}$ & $482^{\mathrm{ab}}$ & $471^{a}$ & $460^{\mathrm{a}}$ & 15.3 & $* * *$ \\
\hline 4 to 20 weeks & $625^{c d}$ & $647^{d}$ & $644^{d}$ & $588^{\mathrm{bc}}$ & $545^{\mathrm{ab}}$ & $546^{\mathrm{ab}}$ & $532^{\mathrm{a}}$ & $510^{\mathrm{a}}$ & 17.6 & $* * *$ \\
\hline
\end{tabular}

$\mathrm{a}, \mathrm{b}, \mathrm{c}, \mathrm{d}, \mathrm{e}$ Means with the same superscript are not significantly different. Data were analysed using Duncan's multiple range test within ANOVA. $* * * P<0.001$

Table 3 The average growth rate (g/day) and estimated days to $100 \mathrm{~kg}$ of pigs in the top and bottom quartile of herds

\begin{tabular}{lcccc}
\hline \hline & Top quartile & Bottom quartile & s.e. & Significance \\
\hline 4 to 8 weeks & 404 & 343 & 12.5 & $* * *$ \\
8 to 12 weeks & 593 & 481 & 15.4 & $* *$ \\
12 to 20 weeks & 810 & 640 & 19.9 & $* * *$ \\
Estimated days to $100 \mathrm{~kg}$ & 162 & 180 & 4.6 & $* * *$ \\
\hline \hline
\end{tabular}

${ }^{* *} P<0.01 ;{ }^{* *} P<0.001$.

data set at any given age. Correlations were established between the weights of pigs at various ages in one case on the top and in the other case on the bottom quartile of herds using Genstat (2002) and taking into consideration farm effects.

\section{Results}

\section{On-farm performance}

The ADG of herds differed significantly $(P<0.001)$ at all stages of growth (Table 2). Overall, from birth or wean to 20 weeks of age, herds $B$ and $C$ had the highest growth rates, while herds $G$ and $H$ had the poorest. Data from herds $B$ and $C$ were amalgamated to represent the top quartile of herds and data from herds $\mathrm{G}$ and $\mathrm{H}$ were amalgamated to represent the bottom quartile of herds (Table 3).

Growth rate differed significantly between the top and bottom quartile of herds by 61,112 and $170 \mathrm{~g} /$ day for the growth periods of 4 to $8(P<0.001), 8$ to $12(P<0.01)$ and 12 to 20 weeks of age $(P<0.001)$ (Table 3$)$. This resulted in the pigs from the top quartile of herds attaining a live weight of $100 \mathrm{~kg}$ on average 18 days earlier than those from the bottom quartile of herds (Table 3).

The coefficient of variation for weight was lower at any stage of growth for pigs on the top quartile of herds than on the bottom quartile of herds (Figure 1).

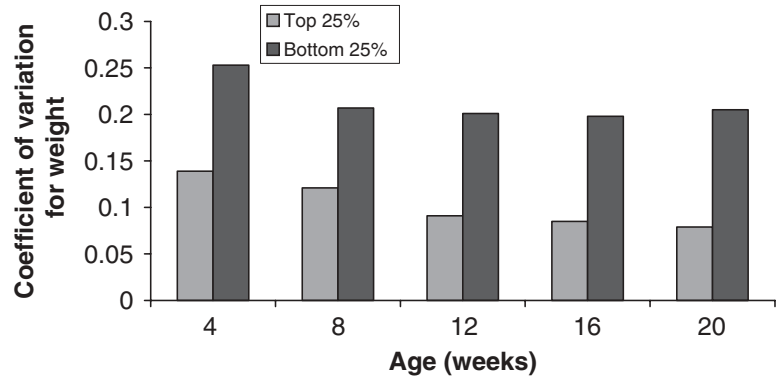

Figure 1 The coefficient of variation for weight of pigs on farm from 4 to 20 weeks of age in the top and bottom quartile of herds.

Overall, the correlations between the weights of pigs at different ages were weaker for pigs from the top quartile of herds than for those from the bottom quartile of herds (Table 4). The correlations between the weights of pigs at different ages from the bottom quartile of herds were strong, highly significant $(P<0.001)$ and similar. The correlations between the weights of pigs from the top quartile of herds tended to weaken as pigs got older and the correlations between the weaning weight and 16 and 20 week weight were not significant.

\section{Economic evaluation}

The top herd was identified as herd $\mathrm{C}$ and the bottom herd as herd $\mathrm{H}$. The total feed cost per pig was greater on the 
bottom farm due to poorer feed efficiency (Table 5). Fewer pigs could be produced per year using 1100 finisher places on the bottom farm due to the slower growth rate (Table 6). A lower carcass weight was also attained due to higher post-weaning mortality on the bottom farm (Table 6).

Table 4 Correlations between the weight of pigs at various ages in the top and bottom quartile of herds ( $\mathrm{n}=44$ each) with farm effects

\begin{tabular}{llllll}
\hline $\begin{array}{l}\text { Age } \\
\text { (weeks) }\end{array}$ & \multicolumn{1}{c}{4} & \multicolumn{1}{c}{8} & \multicolumn{1}{c}{12} & \multicolumn{1}{c}{16} & \multicolumn{1}{c}{20} \\
\hline 4 & $-^{+}$ & $0.863^{* * *}$ & $0.733^{* * *}$ & $0.812^{* * *}$ & $0.800^{* * *}$ \\
8 & $0.565^{* * *}$ & $-^{+}$ & $0.884^{* * *}$ & $0.844^{* * *}$ & $0.836^{* * *}$ \\
12 & $0.461^{* *}$ & $0.816^{* * *}$ & $-^{+}$ & $0.886^{* * *}$ & $0.874^{* * *}$ \\
16 & $0.278^{\text {NS }}$ & $0.610^{* * *}$ & $0.663^{* * *}$ & $-^{+}$ & $0.917^{* * *}$ \\
20 & $0.077^{\mathrm{NS}}$ & $0.447^{* *}$ & $0.463^{* *}$ & $0.861^{* * *}$ & $-^{+}$ \\
\hline \hline
\end{tabular}

${ }^{+}$Values below the diagonal report correlations between the weights of pigs in the top quartile of herds whereas values above the diagonal report correlations between the weights of pigs in the bottom quartile of herds. NS $=$ not significant, ${ }^{*} P<0.05 ;{ }^{* *} P<0.01 ;{ }^{* *} P<0.001$.

Table 5 Feed usage, efficiency and resultant cost per pig on the top herd and bottom herd

\begin{tabular}{lcc}
\hline \hline & Top herd & Bottom herd \\
\hline Feed usage (g/day) & & \\
$\quad$ First stage & 456 & 429 \\
$\quad$ Second stage & 1311 & 1041 \\
$\quad$ Finisher & 2226 & 1836 \\
& & \\
Feed conversion ratio & 1.20 & 1.30 \\
$\quad$ First stage & 2.26 & 2.54 \\
$\quad$ Second stage & 2.80 & 3.06 \\
$\quad$ Finisher & & \\
& & \\
Feed cost & \\
$\quad$ Per kg of feed & 299.8 & 322.8 \\
Cost/tonne ( $€$ per pig) & 71.6 & 76.2 \\
\hline \hline
\end{tabular}

${ }^{\dagger}$ Feed cost $=$ first + second + finisher stage feed costs combined.

NB The average weight of the pigs at 20 weeks of age was taken as the finish weight.
Overall, the difference in herd net profit between the top and bottom herds was $€ 45795$ per year which equated to a difference in carcass value of $\phi 13 / \mathrm{kg}$.

\section{Performance of pigs in the common environment}

The ADG $(P<0.01)$ and average daily feed intake (8 to 12 weeks $P<0.05 ; 12$ to 20 weeks $P<0.001$ ) of pigs from the eight herds differed significantly between herds through both stages of growth in the common environment whereas the feed conversion efficiency differed significantly $(P<0.01)$ only in the early stages (8 to 12 weeks) (Table 7). Pigs from herds $A$ and $B$ tended to have the highest growth rate and feed intake from 8 to 12 and 12 to 20 weeks of age whereas pigs from herds $C$ and $G$ had the lowest. However, the feed conversion ratio (FCR) of pigs from herds $A, B, C$ and $G$ were similar. The FCR of pigs from herds $E$ and $\mathrm{H}$ was significantly $(P<0.01)$ poorer.

Data from herds $A$ and $B$ were amalgamated to represent the top quartile of pigs and data from herds $C$ and $G$ were amalgamated to represent the bottom quartile of pigs in the common environment (Table 8). The ADG and average daily feed intake of the top quartile of pigs was significantly higher from 8 to $12(P<0.01)$ and 12 to $20(P<0.001)$ than that of the bottom quartile of pigs. The top quartile of pigs reached a live weight of $100 \mathrm{~kg}$ on average 19 days earlier $(P<0.001)$. There was no significant difference in the FCR of pigs in the top or bottom quartile.

Table 6 Economic return for top and bottom herd using 1100 finishing pig places

\begin{tabular}{lcc}
\hline \hline & Top herd & Bottom herd \\
\hline $\begin{array}{l}\text { Number of pigs at 105 kg produced } \\
\text { per year }\end{array}$ & 4500 & 3200 \\
Post weaning mortality $(\%)$ & & \\
Carcass weight $(\mathrm{kg})$ & 2.8 & 7.1 \\
Carcass value $(€)$ & 79.90 & 78.45 \\
Total cost per pig $(€)$ & 104.57 & 102.68 \\
Herd net profit $(€)$ & 84.66 & 90.24 \\
\hline \hline
\end{tabular}

Table 7 Performance of pigs from different herds when managed in the common environment

\begin{tabular}{|c|c|c|c|c|c|c|c|c|c|c|}
\hline & \multicolumn{8}{|c|}{ Herd } & \multirow[b]{2}{*}{ s.e. } & \multirow[b]{2}{*}{ Significance } \\
\hline & A & B & $\mathrm{C}$ & D & $\mathrm{E}$ & $\mathrm{F}$ & G & $\mathrm{H}$ & & \\
\hline \multicolumn{11}{|c|}{ Average daily gain (g/day) } \\
\hline 8 to 12 weeks & $838^{\mathrm{c}}$ & $824^{c}$ & $683^{a b}$ & $769^{\text {bc }}$ & $662^{\mathrm{a}}$ & $743^{\mathrm{abc}}$ & $692^{\mathrm{ab}}$ & $690^{\mathrm{ab}}$ & 33.6 & ** \\
\hline 12 to 20 weeks & $1018^{\mathrm{bc}}$ & $1110^{c}$ & $815^{\mathrm{a}}$ & $1023^{b c}$ & $1006^{\mathrm{bc}}$ & $863^{\mathrm{a}}$ & $827^{\mathrm{a}}$ & $946^{\mathrm{ab}}$ & 47.7 & ** \\
\hline \multicolumn{11}{|c|}{ Average daily feed intake (g/day) } \\
\hline 8 to 12 weeks & $1658^{d}$ & $1571^{c}$ & $1310^{\mathrm{ab}}$ & $1519^{\text {bcd }}$ & $1462^{\mathrm{abcd}}$ & $1394^{\mathrm{abc}}$ & $1260^{\mathrm{a}}$ & $1549^{b c d}$ & 80.3 & * \\
\hline 12 to 20 weeks & $2631^{d}$ & $2624^{d}$ & $2010^{\mathrm{ab}}$ & $2462^{\mathrm{cd}}$ & $2413^{\mathrm{cd}}$ & $2206^{\mathrm{abc}}$ & $1935^{a}$ & $2281^{\mathrm{bc}}$ & 94.2 & $* * *$ \\
\hline \multicolumn{11}{|l|}{ Feed conversion ratio } \\
\hline 8 to 12 weeks & $1.97^{\mathrm{a}}$ & $1.91^{\mathrm{a}}$ & $1.92^{\mathrm{a}}$ & $1.97^{\mathrm{a}}$ & $2.21^{\mathrm{b}}$ & $1.89^{\mathrm{a}}$ & $1.82^{a}$ & $2.26^{\mathrm{b}}$ & 0.077 & ** \\
\hline 12 to 20 weeks & 2.56 & 2.37 & 2.47 & 2.42 & 2.40 & 2.56 & 2.34 & 2.41 & 0.063 & NS \\
\hline
\end{tabular}

$\mathrm{a}, \mathrm{b}, \mathrm{c}, \mathrm{d}, \mathrm{e}$ Means with the same superscript are not significantly different.

${ }^{*} P<0.05 ;{ }^{* *} P<0.01 ;{ }^{* * *} P<0.001 ;$ NS $=$ not significant. 
Table 8 Performance of pigs in the top and bottom quartile of herds when managed in the common environment

\begin{tabular}{lrrrr}
\hline \hline & $\begin{array}{c}\text { Top } \\
\text { quartile }\end{array}$ & $\begin{array}{c}\text { Bottom } \\
\text { quartile }\end{array}$ & s.e. Significance \\
\hline $\begin{array}{l}\text { Average daily gain (g/day) } \\
\quad 8 \text { to } 12 \text { weeks }\end{array}$ & 831 & 688 & 16.9 & $* *$ \\
$\quad 12$ to 20 weeks & 1064 & 821 & 41.2 & $* * *$ \\
& & & & \\
& 139 & 158 & 5.1 & $* * *$ \\
Estimated days to $100 \mathrm{~kg}$ & & & & \\
$\begin{array}{l}\text { Average daily feed intake } \\
\text { (g/day) }\end{array}$ & & & & \\
8 to 12 weeks & 1614 & 1285 & 52.8 & $* *$ \\
12 to 20 weeks & 2628 & 1973 & 78.0 & $* * *$ \\
& & & & \\
$\begin{array}{l}\text { Feed conversion ratio } \\
8 \text { to } 12 \text { weeks }\end{array}$ & 1.94 & 1.87 & 0.035 & NS \\
12 to 20 weeks & 2.47 & 2.40 & 0.042 & NS \\
\hline \hline
\end{tabular}

${ }^{* *} P<0.01 ;{ }^{* *} P<0.001 ; \mathrm{NS}=$ not significant.

\section{Discussion}

The financial impact of variable growth rates is not commonly recognised by producers but is a very real and often a hidden cost to the pig industry that is difficult to quantify (Payne et al., 1999). Some attempts have been made to quantify the economic effect of growth rate variation within a group of pigs. Using the 'AUSPIG' simulation model, Payne et al. (1999) estimated that if $100 \%$ of pigs in a group had a level of performance classified as medium, then 'profitability' was $€ 8.97$ per pig sold. However, if the distribution of pigs was such that $20 \%, 60 \%$ and $20 \%$ of the pigs were classified as low, medium and high, respectively, then overall 'profitability' was reduced by $\varnothing 55$ per pig sold. In the current study, the difference in performance between the top and bottom producers equated to an average difference in cost of production of $\phi 13 / \mathrm{kg}$ of carcass on a birth to bacon herd. In addition, larger weight variation occurred at all stages of growth within poorer performing herds implicating large variation in growth rate.

Some variation in growth rate between pigs is inevitable, for example entire male pigs have been shown to grow $7.7 \%$ faster than females, thus creating variation in finish weights (Payne et al., 1999). Frey (1998) listed other sources of variation in the growth rate of grower/finisher pigs including: genotype; disease; management system; weight at entry; group size; space allocation; dominant or submissive behaviour; stockmanship; and season. In the current study, all of the above factors varied between herds except season. However, when pigs were brought to a common environment, the only differences were genotype, pre-weaning environment and health status and weight at entry, yet large variations in growth rate still occurred between pigs from different herds. In addition, within a herd factors like management system, disease exposure, group size, space allocation and stockmanship should have been constant but variation in growth rate within herds was still observed with its extent varying dramatically between herds. It could be suggested that these aforementioned factors were better managed or kept more constant within herds with overall good performance and resulted in lower variable growth within the herd.

As mentioned, variation in the performance of pigs from different herds was also noted when they were managed in the common environment, with variation being similar to that observed on farm. However, although trends were similar, the two top and bottom performing herds in the common environment were not the same as the two top and bottom performing herds 'on farm'. From each herd, three boars, representative of pigs being weaned on farm, were performance tested in the common environment and this, in addition to the medication pigs received on entry, may be a significant factor in the re-ranking of herd performance in the common environment. The top performing pigs in the common environment had a similar feed efficiency but ate significantly more than the poorer performing pigs. Genotype, pre-weaning environment and health status, and weight at entry were the main differences between pigs in the common environment. Although all the same breed, differences in pig genotype may be a significant contributor to the variable growth rate observed between pigs from different herds. Hall et al. (1999) reported coefficients of variation for food conversion ratio of $11 \%$, ADG of $13 \%$ and daily feed intake of $13 \%$ from records of 1832 pigs of a Large White sire line selected for lean tissue growth. These differences were attributed to different phenotypes, i.e. the same genotype interacting with different environments to cause variation (Hall et al., 1999).

Although the effect of disease on growth performance is well documented (Muirhead (1986) cited by English et al., 1988), its effect on variable growth is not (Payne et al., 1999). Variation in growth rate within groups of pigs infected with pneumonia has been found to be up to $80 \%$ greater than that in a group of non-infected pigs (Skirrow, 1993). In addition, Patrick et al. (1993) found that pigs exhibiting clinical disease and then treated, took an additional 15.3 days to reach slaughter weight. In the current study, the disease status of the pigs pre-environment, i.e. on farm from birth to wean, varied between herds and it was noted that pigs from the bottom quartile of herds had visibly more evidence of clinical disease on farm than pigs from the top quartile of herds. This is reflected in the variations in growth rate of pigs within the bottom quartile of herds being much greater than that observed with pigs in the top quartile of herds. Medication of pigs using tylosin and bacitracin methylene disalicylate has been found to decrease variable growth (Tillman, 1997; Deen et al., 1998). In the common environment, although pigs were medicated in order to equilibrate their disease status, it is highly likely that their pre-environment disease exposure affected their subsequent growth rate in the common environment. It is possible that if pigs had not been medicated, variation in growth rate in the common environment may have been even greater. 
On farm, litters of pigs were mixed across different groups, although group size remained constant within a herd. Research evidence suggests that a certain degree of variation in weight of pigs in a group is necessary for the development and maintenance of a social order and, that in the absence of variation in weight when a group is formed, it will develop over time (Tindsley and Lean, 1984; Gonyou, 1998). Hessing et al. (1994) found that when pigs which had an 'active' coping style to stress were mixed with pigs which had a 'passive' coping style, they grew faster with less variation in growth rate $(801 \mathrm{~g} /$ day, $\mathrm{CV}=7.1 \%)$ than when 'active' $(761 \mathrm{~g} /$ day, CV $=11.8 \%)$ and 'passive' $(773 \mathrm{~g} /$ day, $C V=10.5 \%$ ) pigs were grouped separately. In addition, similar variations in growth rate have been found in group sizes ranging from 20 to 60 pigs per pen $\left(0^{\prime}\right.$ Connell et al., 2004).

A strong relationship has been reported between the initial weight of pigs on entry to a finisher unit (12-week weight) and slaughter weight (Patrick et al., 1993), which is in line with results of this study with pigs from the bottom quartile of herds. However, a much weaker relationship between slaughter weight and 12-week weight was observed for pigs on the top quartile of herds.

Several studies have demonstrated the effect of weaning weight on days to market. Mahan and Lepine (1991) showed that pigs weighing from 7.3 to $8.6 \mathrm{~kg}$ at weaning ( 25.3 days old) reached a weight of $105 \mathrm{~kg}$ approximately 15 days earlier than pigs that weighed from 4.1 to $5 \mathrm{~kg}$ at weaning at 23.8 days, regardless of the lighter group being fed a higher quality starter diet than that offered to the heavier pigs. Miller et al. (1999) demonstrated that the weaning weight of pigs in the 1st week after weaning was a significant predicator of subsequent performance, but Slade and Miller (1999) added that the significance of this factor reduced with time post-weaning. Results from the current study support partially these findings, although weaning weight was a good predictor of 20-week weight only for pigs in the bottom quartile of herds. It is also interesting to note that the significance of weaning weight on subsequent weight decreased with time with pigs in the top quartile of herds. The weaker correlation between the wean and 20-week weights for pigs from the top quartile of herds suggests that management factors on the top quartile of herds influenced growth performance to a larger extent than on the poorer herds and promoted faster growth of pigs. Further work is required to quantify the contribution of management practices to the variation in growth rate on commercial pig herds.

Performance of pigs raised under commercial conditions is generally well below their genetic potential (Black et al., 2001). For example, the growth rate of growing and finishing pigs housed individually can increase by up to 200 and $300 \mathrm{~g} /$ day, respectively, compared with when they are housed in groups (Campbell and Taverner, 1985; Weatherup et al., 2002). The depression in performance under commercial conditions may be attributed to a reduction in feed intake (English et al., 1988) and Black et al. (2001) have suggested that a number of factors within a commercial environment may contribute to this including: the number of pigs per pen; space allowance; the prevalence of disease; and the temperament/genotype of the pig. However, in the current study, when pigs were housed individually many of the commercial stressors were absent and large differences in feed intake were still observed. Although the feed efficiency and breed (Large White $\times$ Landrace) of the top and bottom performers in the common environment was similar, it is possible that feed intake was reduced as a result of a lower voluntary feed intake, influenced mainly by differences in pig phenotype. Large variations in the performance of pigs within a breed have been shown by McCann and Beattie (2004).

In conclusion, large variation in growth rate between pigs within herds is a major contributor to poor herd performance and reduced profitability. Within a breed, major variations in feed intake can contribute to the variation in growth rate. More research is required to investigate the interactive effects between nutrition, management and disease and their contribution to the wide variation in growth performance between and within herds. In addition, research should focus on strategies to manage such variation and ultimately to maximise the full genetic growth rate potential of pigs.

\section{Acknowledgements}

The authors gratefully acknowledge the co-operation of the eight pig producers involved in the study. Financial support for the work is also gratefully acknowledged from John Thompson and Sons Ltd, Devenish Nutrition Ltd and the Department of Agriculture and Rural Development for Northern Ireland. We are also thankful for the technical assistance of Agri-Food and Biosciences Institute staff in the care of the animals and the statistical expertise provided by David Kilpatrick.

\section{References}

Black JL, Giles LR, Wynn PC, Knowles AG, Kerr CA, Jones MR, Strom AD, Gallagher NL and Eamens GJ 2001. Factors limiting the performance of growing pigs in commercial environments. In Manipulating pig production VIII (ed. PD Cranwell), pp. 9-36. Australasian Pig Science Association (APSA), Werribee, Victoria, Australia.

Bruininx EMAM, Van der Peet-Schwering CMC and Schrama JW 2001. Individual feed intake of group housed weaned pigs and health status. In The weaner pig, nutrition and management (ed. MA Varley and J Wiseman), pp. 113-122. CABI Publishing, Wallingford, UK.

Campbell RG and Taverner MR 1985. Effect of strain and sex on protein and energy metabolism in growing pigs. In Energy metabolism of farm animals (ed. RW Moe, HF Tyrell and PJ Reynold), pp. 78-81 European Association of Animal Production publication no. 32. Rowan and Littlefield, New Jersey, USA.

David PJ, Johnson RK and Socha TE 1983. Genetic and phenotypic parameters estimated from Nebraska specific-pathogen-free swine filed records. Journal of Animal Science 57, 1117-1123.

Deen J, Dritz S, Watkins L and Weldon W 1998. Feeding tylosin alters the distribution of market pig gains Proceedings of the 15th International Pig Veterinary Society, Birmingham, England p. 211.

Donnelly E 2004. Pig benchmarking. Report 2003-2004. Occasional publication. College of Agriculture, Food and Rural Development, Department of Agriculture and Rural Development for Northern Ireland, UK. 


\section{Magowan, McCann, Beattie, McCracken, Henry, Smyth, Bradford, Gordon and Mayne}

Donnelly E 2006. Pig benchmarking. Report 2005-2006. Occasional publication. College of Agriculture, Food and Rural Development, Department of Agriculture and Rural Development for Northern Ireland, UK.

English PR, Fowler VR, Baxter S and Smith B 1988. Measures of efficiency in pig meat production and the major controlling factors. In The growing and finishing pig: improving efficiency (ed. PR English, VR Fowler, S Baxter and B Smith), pp. 13-25. Framing Press, Ipswich, UK.

Frey B 1998. Novel ways of analysing grower pig performance. Proceedings of the Australian Association of Pig Veterinary, Sydney, Australia, pp. 49-52.

Geary TM and Brooks PH 1998. The effect of weaning weight and age on the post-weaning growth performance of piglets fed fermented liquid diets. The Pig Journal 42, 10-23.

Genstat 2002. Genstat 6.1 reference manual. Clarendon Press, Oxford, UK.

Gonyou HW 1998. Sorting and mixing of grower/finisher pigs Proceedings of the 1998 Allen D. Leman swine conference University of Minnesota, Minnesota, USA, pp. 126-128.

Hall AD, Hill WG, Bampton PR and Webb AJ 1999. Genetic and phenotypic parameter estimates for feeding pattern and performance test traits in pigs. Animal Science 68, 43-48.

Hessing MJC, Schouten WGP, Wiepkema PR and Tielen MJM 1994. Implications of individual behavioural characteristics on performance in pigs. Livestock Production Science 40, 187-196.

Kennedy BW 1984. Between and within litter variation, sex effects and trends in sire and dam transmitting abilities or performance tested pigs in Ontario. Journal of Animal Science 59, 338-345.

McCann MEE and Beattie VE 2004. The effects of sire type on reproduction, production performance and carcass quality of pigs. Report prepared for the Ulster farmers' union (UFU) and the pig production development committee (PPDC) committees. Occasional publication. Agricultural Research Institute of Northern Ireland, UK.

Mahan DC and Lepine AJ 1991. Effect of pig weaning weight and associated nursery feeding programs on subsequent performance to 105 kilograms body weight. Journal of Animal Science 69, 1370-1378.

Miller HM, Toplis P and Slade RD 1999. Weaning weight and daily live weight gain in the week after weaning predict piglet performance. In Manipulating pig production VII (ed. PD Cranwell), p. 130. Australasian Pig Science Association (APSA), Werribee, Victoria, Australia.

Milligan BN, Fraser D and Kramer DL 2001. Birth weight variation in the domestic pig: effects on offspring survival, weight gain and suckling behaviour. Applied Animal Behaviour Science 73, 179-191.
O'Connell NE, Beattie VE and Weatherup RN 2002. Influence of feeder type on the performance and behaviour of weaned pigs. Livestock Production Science 74, 13-17.

O'Connell NE, Beattie VE and Weatherup RN 2004. Influence of group size during the post-weaning period on the performance and behaviour of pigs. Livestock Production Science 86, 225-232.

Pajor EA, Fraser D and Kramer DL 1991. Consumption of solid food by suckling pigs: individual variation and relation to weight gain. Applied Animal Behaviour Science 32, 139-155.

Patrick GF, Hurt CA and Overend C 1993. Marketing concerns in all-in/all-out production, pp. 53-59. Purdue swine day report Purdue University, Purdue, Indiana, USA.

Payne HG, Mullan BP, Trezona M and Frey B 1999. Variation in pig production and performance. In Manipulating pig production VII (ed. PD CRanwell), pp. 13-26. Australasian Pig Science Association (APSA), Werribee, Victoria, Australia.

Skirrow SZ 1993. Effects of stocking arrangements on respiratory disease of pigs. In Manipulating pig production III (ed. ES Batterham), pp. 98-104. Australasian Pig Science Association (APSA), Werribee, Victoria, Australia.

Slade RD and Miller HM 1999. Influences of litter origin and weaning weight on post-weaning piglet growth. In Manipulating pig production VII (ed. PD Cranwell), p. 131. Australasian Pig Science Association (APSA), Werribee, Victoria, Australia.

Stein TE, Duffy SJ and Wickstrom S 1990. Differences in production values between high- and low-productivity swine breeding herds. Journal of Animal Science 68, 3972-3979.

Tillman PD 1997. Methods of improving performance and handling of tail-end pigs Proceedings of the 28th annual meeting of the American Association of Swine Practitioners Quebec City, Canada, pp. 113-115.

Tindsley WEC and Lean IJ 1984. Effects of weight range at allocation on production and behaviour in fattening pig groups. Applied Animal Behaviour Science 12, 79-92.

Weatherup RN, Beattie VE, McCracken KJ, Henry RW, Mclllroy SG and Smyth S 2002. The effects of energy and lysine concentrations in grower diets for pigs on performance from 8 to 12 weeks of age. Irish Journal of Agricultural Food Research 41, 95-104.

Whittemore CT and Green DM 2001. Growth of the young weaned pig. In The weaner pig, nutrition and management (ed. MA Varley and J Wiseman), pp. 1-16. CABI Publishing, Wallingford, UK. 